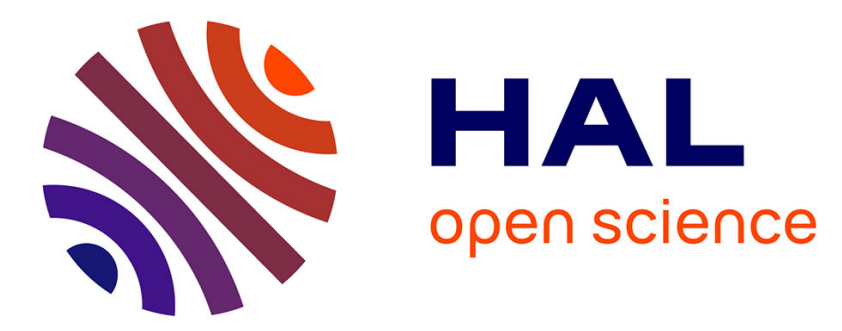

\title{
Evidence for ACD5 ceramide kinase activity involvement in Arabidopsis response to cold stress
}

Christelle Dutilleul, Heidy Chavarria, Nathalie Rézé, Bruno Sotta, Emmanuel Baudouin, Isabelle Guillas

\section{- To cite this version:}

Christelle Dutilleul, Heidy Chavarria, Nathalie Rézé, Bruno Sotta, Emmanuel Baudouin, et al.. Evidence for ACD5 ceramide kinase activity involvement in Arabidopsis response to cold stress. Plant, Cell and Environment, 2015, 38 (12), pp.2688-2697 10.1111/pce.12578 . hal-01229102

\section{HAL Id: hal-01229102 https: / hal.sorbonne-universite.fr/hal-01229102}

Submitted on 16 Nov 2015

HAL is a multi-disciplinary open access archive for the deposit and dissemination of scientific research documents, whether they are published or not. The documents may come from teaching and research institutions in France or abroad, or from public or private research centers.
L'archive ouverte pluridisciplinaire HAL, est destinée au dépôt et à la diffusion de documents scientifiques de niveau recherche, publiés ou non, émanant des établissements d'enseignement et de recherche français ou étrangers, des laboratoires publics ou privés. 
1 Evidence for ACD5 Ceramide Kinase activity involvement in Arabidopsis response to cold 2 stress.

$4 \quad$ Running title: ACD5 in cold stress response

8 Christelle Dutilleul ${ }^{1,2}$, Heidy Chavarria ${ }^{1,3}$, Nathalie Rézé ${ }^{1}$, Bruno Sotta ${ }^{1}$, Emmanuel Baudouin ${ }^{4,5}$ and $9 \quad$ Isabelle Guillas ${ }^{1,6}$

${ }^{1}$ UFR 927, Sorbonne Universités, UPMC Univ Paris 06, F-75252, Paris, France

${ }^{2}$ Present address: Université François-Rabelais de Tours, EA2106 Biomolécules et Biotechnologies

Végétales, UFR Sciences et Techniques, Parc Grandmont, F-37200, Tours, France

$14{ }^{3}$ Present address: Department of Biology, University of Fribourg, Fribourg, Switzerland.

$15{ }^{4}$ Sorbonne Universités, UPMC Univ Paris 06, Institut de Biologie Paris-Seine (IBPS), UMR 7622, 16 F-75252, Paris, France

$17 \quad{ }^{5}$ CNRS, IBPS, UMR 7622, Biologie du Développement, F-75252, Paris, France

$18{ }^{6}$ Corresponding author:

19 Address: Sorbonne Universités, UPMC Univ Paris 06, UFR 927, F-75252, Paris, France

20 Tel: +33-(0)1-42-17-77-97

21 E-mail: isabelle.guillas_baudouin@upmc.fr 
Although sphingolipids emerged as important signals for plant response to low temperature,

investigations have been limited so far to the function of long-chain base intermediates. The formation and function of ceramide phosphates (Cer-P) in chilled Arabidopsis was explored. Cer-P were analysed by TLC following in vivo metabolic radiolabelling. Ceramide kinase activity, gene expression and growth phenotype were determined in unstressed and cold-stressed WT and Arabidopsis ceramide kinase mutant $a c d 5$. A rapid and transient formation of Cer-P occurs in cold stressed WT Arabidopsis plantlets and cultured cells, that is strongly impaired in acd5 mutant. Although concomitant, Cer-P formation is independent of long-chain base phosphate (LCB-P) formation. No variation of ceramide kinase activity was measured in vitro in WT plantlets upon cold stress but the activity in acd5 mutant was further reduced by cold stress. At the seedling stage, acd5 response to cold was similar to that of WT. Nevertheless acd5 seed germination was hypersensitive to cold and ABA, and ABA-dependent gene expression was modified in acd5 seeds when germinated at low temperature. Our data involve for the first time Cer-P and ACD5 in low temperature response and further underline the complexity of sphingolipid signalling operating during cold stress. 
Introduction.

Cold is a major abiotic stress that restrains plant growth and development and affects plant species distribution. Plants from temperate zones are globally tolerant to non-freezing temperatures (chilling) and exhibit different degree of sensitivity when exposed to negative temperature (freezing). Nevertheless, freezing tolerance might be enhanced after acclimation, i.e. pre-treatment at chilling temperature. The use of Omic-based approaches has recently helped identify major genes, proteins and metabolites involved in chilling and/or freezing responses (Knight \& Knight 2012). These data highlighted a global modification of plant metabolism in cold-stressed plants, which at least partly relies on the modifications of gene expression and counterbalances cell dysfunctions under low temperature (Ruelland et al. 2009; Knight \& Knight 2012).

Concurrently with the analysis of the cold-activated molecular programme, a range of cell signals involved in cold transduction has been identified. Alongside calcium and protein kinase/phosphatases, lipid second messengers emerged as important elements of the cold signalling network. This was first evidenced for phosphatidic acid (PdtOH), a ubiquitous signalling molecule derived from membrane phospholipids. Significantly rapid and transient increases of PtdOH production are observed in chilled plants, which are required for proper expression of coldregulated genes (Ruelland et al., 2002; Vergnolle et al., 2005; Arisz et al., 2013). Furthermore modifications of PtdOH metabolism impact plant tolerance to cold (Rajashekar et al., 2006; Li et al., 2011; Delage et al., 2012). More recently, the implication of sphingolipids (SL) in cold transduction pathway has been questioned. SL constitute a family of lipids all sharing a common hydrophobic core, i.e a ceramide (Cer) that results from the condensation of a Long Chain Base (LCB) with a long or a very long chain fatty acid ((V)LCFA)-CoA. Cer are substituted by hydrophilic head groups, giving rise to a tremendously diverse family of complex-SL (Hannun \&

71 Obeid, 2011). By extension, the biosynthesis intermediates, LCB and Cer, are also usually named 
LCB-P and Cer-P formation, respectively. The roles of SL as signalling molecules are now well recognized. In particular, studies carried out in animals evidenced the crucial signalling function of LCB and Cer as well as LCB-P and Cer-P (Bornancin, 2011; Kawabori et al., 2013; Maceyka \& Spiegel, 2014). Noteworthy it appears that LCB/Cer act antagonistically to their phosphorylated counterparts in regulating cell processes as diverse as cell division, differentiation or apoptosis (Mendelson et al., 2014; Aguilera-Romero et al., 2014). The control of the equilibrium between phosphorylated and unphosphorylated forms via the regulation of the specific kinase and phosphatase activities is therefore crucial to maintain cell fitness and determine cell fate (Hoeferlin et al., 2013; Payne et al., 2014). In plants, a growing hand of data indicates that comparable signalling roles could be endowed by SL in response to biotic and abiotic stress ( $\mathrm{Ng}$ et al., 2001; Coursol et al., 2003, 2005; Worrall et al., 2008; Markham et al., 2013; Wu et al., 2015). Pioneering works determined that treatments with LCB-P or LCB kinase inhibitors alter abscisic acid (ABA) responses (Ng et al., 2001; Coursol et al., 2003). Further studies showed that four putative isoforms of LCB kinases exist in Arabidopsis thaliana (Coursol et al., 2005; Worrall et al., 2008; Guo et al., 2011), and illustrated the implication of some of these isoforms in response to ABA (Worrall et al., 2008; Guo et al., 2012). In plants Cer-K activity and Cer/Cer-P balance have been essentially involved in programmed cell death (PCD) and associated to plant-pathogen interactions (Brandwagt et al., 2000; Greenberg et al., 2000; Coursol et al., 2003; Liang et al., 2003; Townley et al., 2005; Raffaele et al., 2008; Bi et al., 2014). As observed in most organisms, a unique gene designated ACCELERATED CELL DEATH5 (ACD5) codes for a Cer-K in Arabidopsis. The sole mutant of this gene described to date is the point mutant $a c d 5$ which presents a reduced Cer-K activity. The $a c d 5$ mutant displays a spontaneous PCD that occurs at late development stages, together with an enhanced sensitivity to pathogen attack (Greenberg et al., 2000; Liang et al., 2003; Bi et al., 2011, 2014). 
Recently, several reports have also associated SL with plant response to low temperature

98 (Cantrel et al., 2011; Chen et al., 2012; Dutilleul et al., 2012; Degenkolbe et al., 2012; Guillas et 99 al., 2012). Beyond the functions of membrane SL in cold acclimation (Steponkus \& Lynch, 1989;

100 Uemura et al., 1995; Minami et al., 2009, 2010), a role for SL as signals has also been evidenced. 101 Indeed, the rapid and transient formation of phytosphingosine-phosphate (PHS-P) has been 102 observed in cold-treated Arabidopsis plantlets (Dutilleul et al., 2012). In this context, the formation 103 of PHS-P required the activity of a particular isoform of LCB kinase designated LCBK2. 104 Interestingly, lcbk2 mutants are affected in specific aspects of cold response such as root growth 105 modulation and cold-responsive gene expression. Together with PHS-P, in vivo labelling 106 experiments indicated the formation of an additional, more hydrophobic SL-related species that we 107 proposed as a putative Cer-P (Cantrel et al., 2011). In the present study, the formation and possible 108 function of this SL during Arabidopsis response to low temperature were further investigated. 109 Analyses of the mutant $a c d 5$ highlight that this particular SL is important for seed germination at 110 low temperature. 
Chemicals

115 Radioactive $\left[{ }^{33} \mathrm{P}\right]$ orthophosphate and $\left[{ }^{33} \mathrm{P}\right] \mathrm{ATP}$ were purchased from Hartmann Analytic

116 (Braunscheig, Germany). C8-Ceramide was purchased from Biomol (TEBU, Le Perray-en117 Yvelines, France). Ceramide kinase inhibitor K1 was purchased from Calbiochem (Merck 118 Millipore, Darmstadt, Germany). Phytosphingosine (PHS) was purchased from Enzo Life Science 119 (Villeurbanne, France). Gibberellic acid, abscissic acid and protease inhibitors were purchased from 120 Sigma-Aldrich (Lyon, France).

Plant and cell cultures

Experiments were performed using Arabidopsis thaliana L. Heynh. wild type (WT) in the Columbia (Col-0) background as cultured cells and seedlings. The acd5 mutant (Greenberg et al., 2000) was kindly provided by Pr J. Greenberg (Uni. Chicago, USA). in vitro-grown seedling cultivation, Arabidopsis seeds were sterilized, stratified for 2 days at $4^{\circ} \mathrm{C}$, and sown on basic 1/2 MS medium (M0221, Sigma-Aldrich, Lyon, France) adjusted at pH 5.7, 0,8\% agar. When specified, $1 \%$ sucrose was added to the medium. Unless stated otherwise, plates were then placed in a growth chamber under continuous illumination $\left(230 \mu \mathrm{E} \cdot \mathrm{m}^{-2} \cdot \mathrm{s}^{-1}\right)$ at $22^{\circ} \mathrm{C}$ and $56 \%$

131 humidity. (Ruelland et al., 2002; Dutilleul et al., 2012).

\section{Cold treatment and plantlet labelling}

Fourteen day-old plantlets (approximatly 50 +/- $5 \mathrm{mg} \mathrm{FW}$ ) were transferred to $50 \mathrm{~mL}$ flasks containing $3 \mathrm{~mL}$ of $1 / 2 \mathrm{MS}$ medium without sugar and agitated overnight at $22^{\circ} \mathrm{C}$ on an orbital 
to each flask, 60 min before cold shock. Cold shock was applied as described previously (Dutilleul

138 et al., 2012). Briefly, flasks were immerged in ice-cold water and maintained under shaking the 139 time specified for the cold treatment. Then plantlets were harvested, briefly soaked and immediately 140 transferred in $5 \mathrm{~mL}$ methanol and frozen in liquid nitrogen. Control plantlets were kept at $22^{\circ} \mathrm{C}$, and 141 harvested in the same manner.

Phosphorylated sphingolipid extraction and analysis

Lipids were subsequently extracted by transferring the samples from liquid nitrogen to water bath maintained at $60^{\circ} \mathrm{C}$ for $15 \mathrm{~min}$ incubation. Subsequently the supernatant was collected and 3 additional extractions were done in the same manner, i.e. $\mathrm{N}_{2}$ frozen, $15 \mathrm{~min}$ at $60^{\circ} \mathrm{C}$ and extracted twice with $3 \mathrm{ml}$ chloroform/methanol (1:1, v/v) and once with $3 \mathrm{ml}$ chloroform. Combined extracts were dried under nitrogen and resuspended in $1 \mathrm{ml}$ methanol. To hydrolyse glycerophospholipids, 1 $\mathrm{ml} 3 \mathrm{~N} \mathrm{NH} \mathrm{NH}_{4} \mathrm{OH} / \mathrm{methanol}(1: 1, \mathrm{v} / \mathrm{v})$ was added to $1 \mathrm{ml}$ total lipid extracts and samples were incubated for $1 \mathrm{~h}$ at $50^{\circ} \mathrm{C}$. The reaction was stopped by neutralization via the addition of $2.5 \mathrm{ml}$ acid acetic/water $(2: 1, \mathrm{v} / \mathrm{v})$. Two successive phase extractions were done by the addition of $2.5 \mathrm{ml}$ 152 chloroform. Combined chloroform phases were nitrogen-dried and sphingolipids were desalted by 153 butanol/water extraction. Briefly sphingolipids were resuspended in $500 \mu 1$ water-saturated butanol. 154 Then $500 \mu \mathrm{l}$ butanol-saturated water was added, samples were vortexed for 1 min and briefly centrifuged to allow phase partitioning. A second extraction was done similarly. Pooled butanol 156 fractions were back extracted with $500 \mu \mathrm{l}$ butanol-saturated water in the same manner ie. $1 \mathrm{~min}$ 157 vortexing followed by a brief centrifugation. Then incorporated radioactivity was estimated by 158 liquid scintillation counting on an aliquot of butanol fraction. Butanol fractions were dried under 159 nitrogen and resuspended in methanol. Sphingolipids were developed by thin-layer chromatography 160 on Silica 60 plates (Merck, Darmstadt, Germany) using chloroform/acetone/methanol/acetic$161 \mathrm{acid} /$ water (10:4:3:2:1; v/v) as solvent system (Wijesinghe et al., 2007). Radiolabeled sphingolipids 
were revealed and quantified using a Storm PhosphorImager (Molecular Dynamics, Sunnyvale, CA, USA). Cold standard PHS-P was visualized after fluorography. For this purpose, plates were sprayed with ninhydrin (Merck, Darmstadt, Germany) and heated to $100^{\circ} \mathrm{C}$ until red spots appeared. C8-Cer-P was detected with orcinol and sulfuric acid (Jork et al., 1990; Reggiori et al., 1997).

In vitro ceramide kinase assay.

Fourteen day-old plantlets were prepared in flasks in liquid media as indicated for labelling assay and submitted or not to cold treatment. They were subsequently harvested, soaked and immediately frozen in liquid $\mathrm{N}_{2}$. The crude plant extracts were prepared as previously described (Liang et al., 2003; Bi et al., 2011). Approximately $50 \mathrm{mg}$ of plantlets were ground in liquid $\mathrm{N}_{2}$ and placed in a $1.5 \mathrm{~mL}$ microfuge tube containing $0.5 \mathrm{~mL}$ of extraction buffer $(20 \mathrm{mM}$ MOPS $\mathrm{pH} 7.2,2$ mM EGTA, $1 \mathrm{mM}$ DTT, $10 \%$ glycerol) supplemented with $1 \mathrm{mM}$ PMSF, $5 \mu \mathrm{M}$ pepstatin and 10 $\mu \mathrm{M}$ leupeptine. The extract was centrifuged for $10 \mathrm{~min}$ at $14000 \mathrm{~g}$, and the supernatant was assayed for protein concentration using Bradford protein assay (Biorad, Marnes la Coquette, France). Cer-K activity was assayed in a final volume of $100 \mu \mathrm{L}$ of reaction buffer $(20 \mathrm{mM}$ MOPS pH 7.2 containing $2 \mathrm{mM}$ EGTA, $1 \mathrm{mM}$ DTT, $10 \%$ glycerol, $10 \mathrm{mM} \mathrm{KCl,} 15 \mathrm{mM} \mathrm{MgCl}$, and $1 \mathrm{mM} \mathrm{ATP}$ ) supplemented with $5 \mu \mathrm{Ci}\left[{ }^{33} \mathrm{P}\right] \mathrm{ATP}$ and $\mathrm{C} 8$-Cer to $50 \mu \mathrm{M}$ final concentration. C8-Cer substrate dissolved in methanol was vacuum-dried in each reaction tube and re-suspended by pipetting in 10 $\mu \mathrm{L}$ of $0.1 \%$ Triton $\mathrm{X}-100$ prior to adding reaction buffer. The reaction was initiated by the addition of $50 \mu \mathrm{g}$ protein and was allowed for $30 \mathrm{~min}$ at $30^{\circ} \mathrm{C}$. It was then stopped by the addition of $600 \mu \mathrm{L}$ chloroform/methanol (1:1, v/v) and $265 \mu \mathrm{L} 2 \mathrm{M} \mathrm{KCl}$. Chloroform phase was $\mathrm{N}_{2}$-dried and desalted by butanol/water partitioning as described above. After $\mathrm{N}_{2}$ drying, lipid extracts were dissolved in $20 \mu \mathrm{L}$ methanol, spotted and developed on Silica 60 plates (Merck, Darmstadt, Germany) in chloroform/acetone/methanol/acetic-acid/water (10:4:3:2:1, v/v). Radiolabelled species were revealed and quantified as described above. 


\section{Phenotypic analyses}

Germination tests were performed using surface sterilized seeds sown on sterile water containing $0,8 \%$ agar. Plates were incubated at $4{ }^{\circ} \mathrm{C}$ for $48 \mathrm{~h}$, and subsequently transferred to $22^{\circ} \mathrm{C}$ or kept at $4{ }^{\circ} \mathrm{C}$. Transfer of control seeds to $22^{\circ} \mathrm{C}$ was considered as $\mathrm{T}_{0}$. Germination was recorded at different time points depending on incubation temperature. Where indicated, filter-sterilized GA or ABA solutions were added to the medium at the indicated concentrations. For ABA experiments, an equivalent volume of DMSO was used for the control.

For root growth tests, seeds were processed as described in the plant culture section. Three day-old plantlets were transferred to $12 \times 12 \mathrm{~cm}$ square plates containing $1 / 2$ strength MS medium and grown vertically. After $24 \mathrm{~h}$ recovery at $22^{\circ} \mathrm{C}$, considered as To, plates were transferred to $12^{\circ} \mathrm{C}$ or kept at $22^{\circ} \mathrm{C}$. Root elongation was recorded every two days over 10 (at $22^{\circ} \mathrm{C}$ ) to 28 (at $12^{\circ} \mathrm{C}$ ) days.

\section{RNA isolation and RT-PCR analyses}

Total RNAs were purified from Arabidopsis plantlets using RNeasy ${ }^{\circledR}$ Plant Mini kit (Qiagen, Courtaboeuf, France) according to manufacturer's procedure. One microgram of total RNA was treated with DNaseI and subsequently reverse-transcribed using Omniscript ${ }^{\circledR}$ RT kit (Qiagen, Valencia, CA, USA). Five time-diluted RT products were used for PCR amplification with DreamTaq ${ }^{\circledR}$ polymerase (Thermo Scientific, Illkirch, France) according to manufacturer’s procedure. The primer sets used are compiled in Supplementary Table 1.

\section{Statistical analysis}

Experimental data reported represent at least three independent biological repeats. When appropriate, results are reported as mean values \pm standard errors. Mean comparisons were calculated by Student test with $P$ values and data sizes indicated in figure legends. 
213 Cold triggers the transient formation of a highly hydrophobic phosphorylated SL

Preliminary experiments indicated that a second phosphorylated lipid related to SL (designated lipid A) was evoked upon cold shock, in addition to PHS-P (Cantrel et al., 2011). We therefore further investigated the characteristics of lipid A formation using in vivo labelling with $\left[{ }^{33} \mathrm{P}\right]$ orthophosphate. In cultured cells lipid A was rapidly detected and migrated with an $\mathrm{Rf}$ of 0.67 .

218 (Fig. 1a, Supplementary figure 1a). Similarly, it was evoked in cold-treated 14 day-old plantlets 219 (Fig. 1b). Co-migration experiments indicated that lipid A migrated at the same Rf in both models suggesting that the same molecular species was formed in the two plant materials upon cold exposure (Supplementary Fig.1b). In both plant materials, no accumulation of lipid A could be observed at $22^{\circ} \mathrm{C}$ within the time of the labelling experiment (Fig. 1a,b $22^{\circ} \mathrm{C}$ panels). Slight differences in kinetics were observed between plantlets and cultured cells. The maximum accumulation of lipid A was progressively reached after $10 \mathrm{~min}$ in cell culture and rapidly decreased back to initial state after 240 min (Fig. 1a,c). In plantlets, a dramatic accumulation of lipid A was observed within 5 min., slightly increasing to a maximum after $30 \mathrm{~min}$ and slowly decreasing thereafter (Fig. 1b,d). Our analysis also indicated differences in the proportion of lipid A

228 abundance in the total labelled lipid spotted. Indeed it represented 30\% at the highest in cultured cells and 50\% in labelled plantlets (Fig. 1c,d). Altogether these data show that a strongly hydrophobic base-resistant phosphorylated lipid was transiently evoked upon cold treatment.

232 ACD5 Cer-K activity is responsible for the phosphorylation of lipid A.

233 The fact that lipid A was base-resistant linked it up to sphingolipids. Moreover its Rf of +/- 0.67 234 identified it as a putative Cer-P (Bielawska et al., 2001, Wijesinghe et al., 2007). To fully establish 235 the identity of lipid A, labelling experiments on mutants affected in ACD5 ceramide Kinase were performed. We identified two heterozygous ACD5 insertion lines available at Nask (Line N582554, 
Line N629619). Nevertheless no homozygous plants from these lines could be obtained, suggesting

238 that acd5 KO mutants were lethal. Therefore, for these analyses, the A. thaliana acd5 knock down

239 mutant exhibiting a G412R point mutation already described (Greenberg et al., 2000) was used. As

240 for the experiments presented in Figure 1, 14 day-old in vitro grown plantlets were used. At this

241 stage $\operatorname{acd} 5$ plantlets are phenotypically similar to WT (Fig. 2a). Furthermore, PRI gene was not

242 expressed in acd5 14 days old mutant plantlets exposed or not to cold (Fig. 2b), indicating that

243 plantlets were not undergoing PCD at this stage of development (Greenberg et al., 2000).

244 Therefore, this material appeared suitable for subsequent in planta labelling and cold response

245 monitoring. The $\left[{ }^{33} \mathrm{P}\right]$ labelled lipid $\mathrm{A}$ was quantified after 3 min of cold shock. In these conditions

246 lipid A increased by $60 \%$, ie. $1.6 \pm 0.21$ fold, in WT plantlets $(8.6 \pm 0.10 \%$ to $14.5 \pm 0.12 \%$ of total

247 lane radioactivity) whereas it only increased by $20 \%$, ie. $1.2 \pm 0,08$, fold in the acd5 mutant ( $8.75 \pm$

$2480.07 \%$ to $10.5 \pm 0.14 \%$ of the total lane radioactivity) (Fig. 2c). These results showed that the lipid

249 A formation required ACD5 Cer-K activity and thereby established that it was a bona fide Cer-P.

250 Therefore, the designation Cer-P will be used thereafter instead of lipid A.

252 Cold-evoked Cer-P and PHS-P formation occurs independently.

253 We previously reported that PHS-P accumulated in response to cold and that this 254 accumulation was defective in the LCBK mutant $l c b k 2$ (Dutilleul et al., 2012). As Cer-P and PHS-P 255 appeared within the same time frame, a possible interdependence of the formation of these two 256 species was investigated. In this view, PHS-P and Cer-P have been quantified in $a c d 5$ and $l c b k 2$ 257 plantlets, respectively (Fig 3). As shown in Figure 3a, PHS-P appearance was not affected by acd5 258 mutation. Conversely, Cer-P accumulation was comparable in cold-stressed WT and $l c b k 2$ plantlets 259 (Fig. 3b). As shown on Figure 3b, similar results were obtained in two other Arabidopsis LCBK 260 mutants, $l c b k 1$ and sphkl (Worrall et al., 2008). These observations indicated that PHS-P and Cer-P 261 formation, whilst concomitant, occurred independently. 
Evaluation of the ACD5 activity modulation in response to cold.

To investigate whether the Cer-P accumulation observed during cold response was due to an

264 enhanced Cer-K activity, Cer kinase activity in vitro using crude protein extracts from plantlets exposed or not to cold was measured. Previous studies using Arabidopsis thaliana crude protein extract showed that C8-Cer was the preferred substrate for Cer-kinase activity in vitro (Liang et al., 2003). Therefore we monitored the formation of $\left[{ }^{33} \mathrm{P}\right]-\mathrm{C} 8$-Cer-P using crude protein extracts from WT plantlets formerly exposed to cold or maintained at $22^{\circ} \mathrm{C}$. In both case a strong Cer kinase activity was observed (Fig. 4a,b, and supplemental Fig 2). As control, no signal corresponding to C8-Cer-P could be observed in absence of C8-Cer substrate or of plant extract (Fig. 4b). In addition, activity measurements in the presence of the Cer-K inhibitor $\mathrm{K} 1$ which partially and specifically inhibits recombinant rice Cer-K activity in vitro (Bi et al., 2011) was performed. The treatment with

273 K1 inhibitor led to a 40\% inhibition of Cer-P phosphorylation (Fig. 4a,b). These results evidenced that the difference in Cer phosphorylation observed in vivo upon cold shock was not correlated with a modification of the Cer-K catalytic activity as measured in vitro. The same experiment was carried out using acd5 plantlet protein extracts. Cer-K activity measured in extracts of unstressed acd5 plantlets was $20 \%$ lower than that of unstressed WT plantlets protein extract (Fig. 4a,b). Surprisingly, an additional decrease of $20 \%$ was observed when the assay was performed with extracts from cold-stressed acd5 plantlets that consequently retained only $60 \%$ of the activity of WT plantlet extracts (Fig. 4a,b), similarly to previous observations (Bi et al., 2011). These data suggested that cold stress exacerbated the consequences of the mutation on ACD5 Cer-K activity. Previous works have shown that $A C D 5$ expression was up regulated in response to pathogen 283 infection suggesting that such regulation may account for ACD5 function in plant defence (Liang et al., 2003; Bi et al., 2014). The possibility that such regulation may occur in response to cold was assessed. Within $4 \mathrm{~h}$ of cold exposure no change in ACD5 transcript abundance was observed in WT plantlets, whereas a slight increase was observed in the acd5 mutant (Fig. 4c). 
Altogether these results suggest a complex array of regulation for ACD5 activity in planta upon cold stress.

\section{Effect of Cer-P accumulation defect on the response of acd5 plantlets to cold.}

To get insights into the involvement of Cer-P accumulation during cold stress, the 292 phenotypic and molecular responses of acd5 mutant to cold was analysed. Due to the pleiotropic 293 effects of acd5 mutation at later developmental stages (i.e. spontaneous cell death, necrosis, PRI 294 activation, Cer accumulation) (Greenberg et al., 2000; Bi et al., 2014), all the analysis were carried out for no longer than four weeks. As the monitoring of root growth at $4{ }^{\circ} \mathrm{C}$ required at least 6 weeks (Dutilleul et al., 2012) it could not be performed with acd5 mutant. Therefore, the root growth was analyzed at $12^{\circ} \mathrm{C}$. With regard to root growth, no significant differences were observed between 298 WT and $\operatorname{acd} 5$ plantlets, neither at $22^{\circ} \mathrm{C}$ nor at $12^{\circ} \mathrm{C}$ (Fig. 5a and supplemental Fig 3). In addition, 299 the expression of cold-responsive transcription factors (CBF1-3, Zat10, Zat12) was assessed in WT and acd5 plantlets. As expected, transcripts of these genes were more abundant following a $4 \mathrm{~h}$ cold treatment in WT plantlets (Fig. 5b and supplemental Fig 3). No significant difference was observed in cold-stressed acd5 plantlets as compared to WT (Fig. 5b). These data showed that the defect in

303 Cer-P accumulation observed in acd5 plantlets did not affect the expression of major cold responsive markers. Yet we observed that the induction of $N O I 3$, previously identified as a coldresponsive gene (Dutilleul et al., 2012), was defective in acd5 (Fig. 5b). As NOI3 gene was also found as a target for PHS signalling, this result further evidenced the link between NOI3 expression and SL signalling in cold response. These observations also suggested that the control of NOI3 expression was operated independently by both PHS-P and Cer-P upon cold shock.

\section{Effect of acd5 mutation on seed germination at low temperature.}


Several reports have evidenced that cold delays the emergence of radicle and globally slows down the germination process in a temperature-dependent manner (Xu et al., 2011, Jung et al., 2015). To further investigate the response of $\operatorname{acd} 5$ mutant to cold, its germination rate was compared with that of WT seeds at $22^{\circ} \mathrm{C}, 12^{\circ} \mathrm{C}$ and $4^{\circ} \mathrm{C}$. At $22^{\circ} \mathrm{C}$, germination was complete 3 days after sowing for both genotypes, indicating that $\operatorname{acd} 5$ seeds were fully germinative under optimal conditions (Fig. 6a). In contrast, at $12^{\circ} \mathrm{C}$ and $4^{\circ} \mathrm{C}$, acd5 seeds germination was significantly and proportionally reduced compared to WT. Thus, as compared to WT, acd5 germination was lowered by $12 \%$ and $49 \%$ respectively at $12^{\circ} \mathrm{C}$ and $4{ }^{\circ} \mathrm{C}$ fourteen days after sowing (Fig. 6a). Acd5 seed germination therefore appeared as hypersensitive to low temperature.

Germination is a complex process controlled by multiple factors, and in particular by the two antagonistic hormones, ABA and GA. Several studies suggested a link between these two regulators and plant response to cold (Chung \& Parish, 2008; Wang et al., 2014, Sasaki et al., 2015). Thus the analysis of the expression of genes involved in ABA and GA metabolism or signalling in WT and $a c d 5$ seeds germinated for 14 days at $4{ }^{\circ} \mathrm{C}$ was done. NCED3, 6 and 9 encode enzymes of the ABA biosynthesis pathway, whereas $A B I 5$ codes for an ABA-responsive transcription factor repressing germination (Lopez-Molina et al., 2001). RGL2 encodes a member of the DELLA family controlled by the GA pathway, and is considered as the main DELLA involved in germination repression (Lee et al., 2002; Tyler et al., 2004). Both RGL2 and ABI5 are upregulated by ABA (Lopez-Molina et al., 2001), and RGL2 itself stimulates ABA synthesis and therefore ABI5 accumulation, (Piskurewicz et al., 2008; Achard \& Genschik, 2009). NCED3 and 9

331 transcripts were accumulated in WT and $\operatorname{acd} 5$ mutant seeds at similar level. In contrast, NCED6 332 transcripts were not detected in WT seeds but accumulated in acd5 seeds (Fig. 6b and supplemental 333 Fig 3). Similarly $A B I 5$ and RGL2 transcripts were more abundant in acd5. Altogether these results 334 indicated that the hypersensitivity of $a c d 5$ germination at low temperature was correlated with an 335 impairment of ABA and GA dependent-gene expression. As shown on Figure 6c, the addition of 
$336 \mathrm{GA}$ in the medium restored $a c d 5$ germination rate at $4{ }^{\circ} \mathrm{C}$ to the level of WT seeds. Finally, a hypersensitivity of $a c d 5$ seeds to ABA was observed (Fig 7). Indeed, the germination rate of acd5 seeds at $22^{\circ} \mathrm{C}$ was $45 \%, 65 \%$ and $86 \%$ lower than that of WT seeds in the presence of 5,10 and 15 $\mu \mathrm{M}$ ABA, respectively. Taken together, these data suggest that defects in the ABA/GA balance linked to Cer-K activity impairment might be responsible for acd5 seed hypersensitivity to cold.

\section{Discussion.}

In the present report we further investigated the implication of sphingolipids in plant response to cold, with a focus on Cer-P. Our results show that a sphingolipid species related to Cer$\mathrm{P}$ is rapidly and transiently evoked in Arabidopsis plantlets and in cultured cells upon cold shock. In addition to its base-resistance and Rf characteristics, which strongly identifies this lipid as being a Cer-P (Wijesinghe et al., 2007), its formation was impaired in the acd5 mutant. ACD5 encodes the unique Cer-K in Arabidopsis and has been previously involved in plant response to pathogens (Liang et al., 2003; Bi et al., 2014). Using in vivo labelling of phosphorylated lipids, a $70 \%$ decrease of cold-evoked Cer-P formation in the $\operatorname{acd} 5$ mutant after cold exposure as compared to WT was observed. The level of Cer-P formed following cold exposure in acd5 plantlets is therefore

352 in good accordance with a lower Cer-K activity of this mutant already measured in vitro using acd5 353 plant extracts (Liang et al., 2003, Bi et al., 2011). Moreover, these data directly linked ACD5 activity to the cold-evoked Cer-P accumulation by the detection of Cer-P in vivo and suggest that this enzyme might be regulated under cold stress. Such modulations of Cer-K activity in vivo have

356 been evidenced in mammal cells (Rovina et al., 2010) and the present study suggests that they also 357 take place in plants for transiently modifying Cer-P abundance. A series of reports have recently 358 illustrated modifications of SL metabolism during cold response at the level of LCB/LCB-P and complex SL (Cantrel et al., 2011; Chen et al., 2012; Dutilleul et al., 2012; Guillas et al., 2012). The analysis of mutants of Cer-P and LCB-P metabolism suggests that the transient formations of PHS- 
$361 \mathrm{P}$ and Cer-P upon cold stress are not interdependent. Further investigations are now required to 362 unravel how these events are coordinated and integrate in the overall stress response.

364 role for this molecule as a signal during cold response. Nevertheless neither short nor long term 365 responses to cold were affected in $\operatorname{acd} 5$ mutant at the vegetative stage. In good agreement with our 366 phenotypic observations, the expression of canonical cold-responsive genes such as $C B F$ s or Zat12 367 was not impaired in stressed acd5 plantlets. This might be due to the residual Cer-P formed by acd5 368 mutant that would be sufficient for triggering cold responses. It might also indicate that additional 369 signals compensate for Cer-P defect. Finally the lack of phenotype might reflect that Cer-P is not a 370 major determinant of cold acclimation in plantlets. Nevertheless, the induction by cold of NOI3, a 371 gene of unknown function that we identified as cold-regulated (Dutilleul et al., 2012), was strongly 372 impaired in acd5 mutant indicating that the impairment of Cer-P might affect specific cold responses. As NOI3 is also regulated by PHS-P, it might constitute a generic target for SL 374 signalling in plants.

375 In contrast with the absence of phenotype at the plantlet stage, acd5 seed germination 376 appeared hypersensitive to low temperature. Germination is regulated by ABA and GA, two 377 hormones that function antagonistically (Finkelstein et al., 2002; Schwechheimer \& Willige, 2009). 378 We found that acd5 seed germination was hypersensitive to ABA, suggesting that the germination 379 defect of acd5 seeds at low temperatures might involve ABA-dependent processes. As no 380 germination defect is observed at $22^{\circ} \mathrm{C}$, it is unlikely that dry acd5 seeds present higher endogenous 381 ABA levels. Furthermore GA treatment reverted $a c d 5$ germination phenotype at $4^{\circ} \mathrm{C}$ pointing 382 towards dysfunctions of GA/ABA regulation at low temperature in acd5 seeds. Supporting this 383 hypothesis, the expression of NCED6, ABI5 and RGL2 remained high in acd5 seeds germinated at $3844{ }^{\circ} \mathrm{C}$ and could afford for repressing germination (Lopez-Molina et al., 2001). As a whole, it 385 suggests that ABA-dependent mechanisms leading to germination inhibition are exacerbated in 
acd5 seeds, in good correlation with the observed phenotypes. How ACD5 CerK activity

participates in ABA signalling in seeds is currently unknown. Noteworthy a recent study reported that atcerl ceramidase mutants present strongly reduced ABA-induced stomatal closure (Wu et al., 2015). Together, these studies suggest new functions for Cer metabolism in ABA response. Although in vivo analyses clearly established an ACD5-dependent de novo accumulation of

Cer-P upon cold stress, in vitro Cer-K activity was identical in extracts from unstressed or coldstressed plantlets. A similar discrepancy has been previously observed in Cos7 cells subjected to osmotic stress and was attributed to the regulation of Cer-K in vivo via its translocation to plasma membrane (Kim et al., 2006). More generally, localisation has been proposed as a critical factor for

Cer-K activity and/or regulation (Carré et al., 2004; Rovina et al., 2009; Bornancin, 2011). Bi et al. (2014) reported that ACD5 is located in different membranes, and proposed that ACD5 could shuttle and thereby get regulated in vivo upon stress, what would be lost when cell integrity is disrupted. In addition, as shown by Boath et al. (2008), Cer-P undergo a rapid turnover in vivo. Cold could therefore also affect Cer-P level by lowering Cer-P degradation via the inhibition of Cer-P phosphatases. Further investigations on this hypothesis will require the characterization of 401 putative Cer-P phosphatases that are currently unidentified in eukaryotes. extracted from unstressed acd5 plantlets, it exhibited a $20 \%$ reduced activity compared to WT ACD5, but the inhibition rose to $40 \%$ when proteins were extracted from cold-stressed plantlets. This last value agrees those reported by $\mathrm{Bi}$ et al. (2011) when using older plants i.e. plants undergoing PCD. As Cer-K activity was measured in vitro under controlled conditions, this further 407 reduction of activity is likely a consequence of a stable alteration of acd5 acquired in planta and 408 triggered by cold. Noteworthy, the G412R point mutation stands in a highly-conserved CC1 region, predicted as a beta helix (Bornancin, 2011). A destabilisation of the enzyme structure caused by the G412R mutation might therefore be amplified by temperature changes. In this respect the up- 
411 regulation of $A C D 5$ gene transcription observed in acd5 mutant exposed to cold could constitute a compensatory mechanism to cope with the additional loss of Cer-K activity triggered by cold. Taken together our data bring the direct evidence for the implication of the Cer-K ACD5 in 414 abiotic stress response. It now paves the way for unravelling the underlying regulatory mechanisms 415 and addressing the versatility of Cer-K participation in plant response to environmental cues.

\section{Acknowledgment}

418 We thank Pr J. Greenberg (University of Chicago, USA) for providing acd5 seeds. We thanks 419 Andrea Davrinche for technical help and constant enthusiasm. We are grateful to Dr O. Lamotte 420 (University of Burgundy, France) for providing us salicylic acid-treated plants. This work was 421 supported by the Ministère de la Recherche et de l'Enseignement Supérieur, by the Centre National 422 de la Recherche Scientifique (CNRS) and by the Université Pierre et Marie Curie. C.D. was a 423 recipient of a post-doctoral fellowship from CNRS (2006-2008). 
Achard, P., and Genschik, P. (2009). Releasing the brakes of plant growth: how GAs shutdown

DELLA proteins. J. Exp. Bot. 60, 1085-1092.

Aguilera-Romero A, Gehin C, Riezman H. 2014. Sphingolipid homeostasis in the web of metabolic routes. Biochimica and Biophysica Acta 1841: 647-656.

Arisz SA, van Wijk R, Roels W, Zhu J-K, Haring MA, Munnik T. 2013. Rapid phosphatidic acid accumulation in response to low temperature stress in Arabidopsis is generated through diacylglycerol kinase. Frontiers in Plant Science 4: 1-15.

Bi F-C, Liu Z, Wu J-X, Liang H, Xi X-L, Fang C, Sun T-J, Yin J, Dai G-Y, Rong C, et al. 2014. Loss of ceramide kinase in Arabidopsis impairs defenses and promotes ceramide accumulation and mitochondrial $\mathrm{H}_{2} \mathrm{O}_{2}$ bursts. Plant Cell 26:3449-67.

Bi F-C, Zhang Q-F, Liu Z, Fang C, Li J, Su J-B, Greenberg JT, Wang H-B, Yao N. 2011. A conserved cysteine motif is critical for rice ceramide kinase activity and function. PloS One 6: e18079.

Bielawska, A, Perry, DK, Hannun, YA. 2001. Determination of Ceramides and Diglycerides by 441 the Diglyceride Kinase assay. Analytical Biochemistry 298: 141-150.

Boath A, Graf C, Lidome E, Ullrich T, Nussbaumer P, Bornancin F. 2008. Regulation and

443 traffic of ceramide 1-phosphate produced by ceramide kinase: comparative analysis to 444 glucosylceramide and sphingomyelin. The Journal of Biological Chemistry 283: 8517-8526.

445 Bornancin F. 2011. Ceramide kinase: the first decade. Cellular Signalling 23: 999-1008.

446 Brandwagt BF, Mesbah LA, Takken FLW, Laurent PL, Kneppers TJA, Hille J, Nijkamp 447 HJJ. 2000. A longevity assurance gene homolog of tomato mediates resistance to Alternaria 448 alternata f. sp lycopersici toxins and fumonisin B-1. Proceedings of the National Academy of 449 Science, USA 97: 4961-4966. 
Zachowski A, Baudouin E. 2011. Nitric oxide participates in cold-responsive phosphosphingolipid formation and gene expression in Arabidopsis thaliana. New Phytologist 189: 415-427.

Bornancin F. 2004. Ceramide kinase targeting and activity determined by its N-terminal pleckstrin homology domain. Biochemical and Biophysical Research Communications 324: 1215-1219.

456 Chen M, Markham JE, Cahoon EB. 2012. Sphingolipid $\Delta 8$ unsaturation is important for glucosylceramide biosynthesis and low-temperature performance in Arabidopsis. Plant Journal 69: 769-781.

Chung S, Parish RW. 2008. Combinatorial interactions of multiple cis-elements regulating the 460 induction of the Arabidopsis XERO2 dehydrin gene by abscisic acid and cold. Plant Journal 54: $15-29$.

Coursol S, Fan LM, Le Stunff H, Spiegel S, Gilroy S, Assmann SM. 2003. Sphingolipid signalling in Arabidopsis guard cells involves heterotrimeric G proteins. Nature 423: 651-654.

Coursol S, Le Stunff H, Lynch DV, Gilroy S, Assmann SM, Spiegel S. 2005. Arabidopsis sphingosine kinase and the effects of phytosphingosine-1-phosphate on stomatal aperture. Plant 466 Physiology 137: 724-737.

Degenkolbe T, Giavalisco P, Zuther E, Seiwert B, Hincha DK, Willmitzer L. 2012. Differential remodeling of the lipidome during cold acclimation in natural accessions of Arabidopsis thaliana. Plant Journal 72: 972-982.

Delage E, Puyaubert J, Zachowski A, Ruelland E. 2012. Signal transduction pathways involving 471 phosphatidylinositol 4-phosphate and phosphatidylinositol 4,5-bisphosphate: Convergences and divergences among eukaryotic kingdoms. Progress in lipid research 53: 565-576. 

activation and Arabidopsis response to chilling. New Phytologist 194: 181-191.

Finkelstein RR, Gampala SSL, Rock CD. 2002. Abscisic acid signaling in seeds and seedlings. Plant Cell 14 Suppl: S15-S45.

Greenberg JT, Silverman FP, Liang H. 2000. Uncoupling salicylic acid-dependent cell death and defense-related responses from disease resistance in the Arabidopsis mutant acd5. Genetics 156: $341-350$.

Guillas I, Guellim A, Rezé N, Baudouin E. 2012. Long chain base changes triggered by a short exposure of Arabidopsis to low temperature are altered by AHb1 non-symbiotic haemoglobin overexpression. Plant Physiology and Biochemistry 63: 191-195.

484 Guo L, Mishra G, Markham JE, Li M, Tawfall A, Welti R, Wang X. 2012. Connections 485 between sphingosine kinase and phospholipase $\mathrm{D}$ in the abscisic acid signaling pathway in Arabidopsis. Journal of Biological Chemistry 287: 8286-8296.

Guo L, Mishra G, Taylor K, Wang X. 2011. Phosphatidic acid binds and stimulates Arabidopsis sphingosine kinases. Journal of Biological Chemistry 286: 13336-13345.

Hannun YA, Obeid LM. 2011. Many ceramides. Journal of Biological Chemistry 286: 2785527862.

Hoeferlin LA, Wijesinghe DS, Chalfant CE. 2013. The role of ceramide-1-phosphate in biological functions. Handbook of Experimental Pharmacology: 153-166.

Jork H, Funk w, Fischer W, Wimmer H. 1990. Thin-layer chromatography, reagents and 494 detection methods. Weinheim: VCH-Verlag. Jung CG, Hwang S-G, Park YC, Park HM, Kim DS, Park DH, Jang CS. 2015. Molecular characterization of the cold- and heat-induced Arabidopsis PXL1 gene and its potential role in transduction pathways under temperature fluctuations. Journal of Plant Physiology 176C: 138-146. 
Kawabori M, Kacimi R, Karliner JS, Yenari MA. 2013. Sphingolipids in cardiovascular and cerebrovascular systems: Pathological implications and potential therapeutic targets. World Journal of Cardiology 5: 75-86.

501 Kim T-J, Mitsutake S, Igarashi Y. 2006. The interaction between the pleckstrin homology 502 domain of ceramide kinase and phosphatidylinositol 4,5-bisphosphate regulates the plasma 503 membrane targeting and ceramide 1-phosphate levels. Biochemical and Biophysical Research 504 Communications 342: 611-617.

505 Knight MR, Knight H. 2012. Low-temperature perception leading to gene expression and cold 506 tolerance in higher plants. New Phytologist 195: 737-751.

507 Lee S, Cheng H, King KE, Wang W, He Y, Hussain A, Lo J, Harberd NP, Peng J. 2002. 508 Gibberellin regulates Arabidopsis seed germination via RGL2, a GAI/RGA-like gene whose 509 expression is up-regulated following imbibition. Genes and Development 16: 646-658.

510 Li X, Wang X, Yang Y, Li R, He Q, Fang X, Luu D-T, Maurel C, Lin J. 2011. Single-molecule 511 analysis of PIP2;1 dynamics and partitioning reveals multiple modes of Arabidopsis plasma 512 membrane aquaporin regulation. Plant Cell 23: 3780-3797.

513 Liang H, Yao N, Song LT, Luo S, Lu H, Greenberg LT. 2003. Ceramides modulate programmed 514 cell death in plants. Genes and Development 17: 2636-2641.

515 Lopez-Molina L, Mongrand S, Chua NH. 2001. A postgermination developmental arrest 516 checkpoint is mediated by abscisic acid and requires the ABI5 transcription factor in Arabidopsis. 517 Proceedings of the National Academy of Sciences, USA 98: 4782-4787.

518 Maceyka M, Spiegel S. 2014. Sphingolipid metabolites in inflammatory disease. Nature 510: 5851967.

520 Markham JE, Lynch DV, Napier JA, Dunn TM, Cahoon EB. 2013. Plant sphingolipids: 521 function follows form. Current Opinion in Plant Biology 16: 350-357.

522 Mendelson K, Evans T, Hla T. 2014. Sphingosine 1-phosphate signalling. Development 141: 5-9. 
524 M. 2009. Alterations in detergent-resistant plasma membrane microdomains in Arabidopsis thaliana

525

526

527

528 during cold acclimation. Plant and Cell Physiology 50: 341-359.

Minami A, Furuto A, Uemura M. 2010. Dynamic compositional changes of detergent-resistant plasma membrane microdomains during plant cold acclimation. Plant Signaling and Behavior 5: $1115-1118$.

Ng CKY, Carr K, McAinsh MR, Powell B, Hetherington AM. 2001. Drought-induced guard cell signal transduction involves sphingosine-1-phosphate. Nature 410: 596-599.

Payne AW, Pant DK, Pan T-C, Chodosh LA. 2014. Ceramide kinase promotes tumor cell survival and mammary tumor recurrence. Cancer Research 74: 6352-6363.

Piskurewicz, U., Jikumaru, Y., Kinoshita, N., Nambara, E., Kamiya, Y., and Lopez-Molina, L. (2008). The Gibberellic Acid Signaling Repressor RGL2 Inhibits Arabidopsis Seed Germination by Stimulating Abscisic Acid Synthesis and ABI5 Activity. Plant Cell Online 20, 2729-2745.

Raffaele S, Vailleau F, Léger A, Joubès J, Miersch O, Huard C, Blée E, Mongrand S, Domergue F, Roby D. 2008. A MYB transcription factor regulates Very-Long-Chain Fatty Acid biosynthesis for activation of the hypersensitive cell death response in Arabidopsis. Plant Cell 20: $752-767$.

Rajashekar CB, Zhou HE, Zhang Y, Li W, Wang X. 2006. Suppression of phospholipase Dalpha1 induces freezing tolerance in Arabidopsis: response of cold-responsive genes and osmolyte accumulation. Journal of Plant Physiology 163: 916-926.

Reggiori F, Canivenc-Gansel E, Conzelmann A. 1997. Lipid remodeling leads to the introduction and exchange of defined ceramides on GPI proteins in the ER and Golgi of Saccharomyces cerevisiae. EMBO Journal 16: 3506-3518.

Rovina P, Graf C, Bornancin F. 2010. Modulation of ceramide metabolism in mouse primary macrophages. Biochemical and Biophysical Research Communications 399: 150-154. 
549 localization of ceramide kinase and ceramide kinase-like protein requires interplay of their

550 Pleckstrin Homology domain-containing N-terminal regions together with C-terminal domains.

551 Biochimica and Biophysica Acta 1791: 1023-1030.

552 Ruelland E, Cantrel C, Gawer M, Kader JC, Zachowski A. 2002. Activation of phospholipases

$553 \mathrm{C}$ and D is an early response to a cold exposure in Arabidopsis suspension cells. Plant Physiology

554 130: 999-1007.

555 Ruelland E, Vaultier MN, Zachowski A, Hurry V. 2009. Cold Signalling and Cold Acclimation

556 in Plants. Advances in Botanical Research, 49: 35-150.

557 Sasaki K, Kim M-H, Kanno Y, Seo M, Kamiya Y, Imai R. 2015. Arabidopsis COLD SHOCK

558 DOMAIN PROTEIN 2 influences ABA accumulation in seed and negatively regulates germination.

559 Biochemical and Biophysical Research Communications 456: 380-384.

560 Schwechheimer C, Willige BC. 2009. Shedding light on gibberellic acid signalling. Current 561 Opinion in Plant Biology 12: 57-62.

562 Steponkus PL, Lynch DV. 1989. Freeze/thaw-induced destabilization of the plasma membrane 563 and the effects of cold acclimation. Journal of Bioenergetics and Biomembranes 21: 21-41.

564 Townley HE, McDonald K, Jenkins GI, Knight MR, Leaver CJ. 2005. Ceramides induce 565 programmed cell death in Arabidopsis cells in a calcium-dependent manner. Biological Chemistry 566 386: 161-166.

567 Tyler L, Thomas SG, Hu J, Dill A, Alonso JM, Ecker JR, Sun T. 2004. DELLA Proteins and 568 Gibberellin-regulated seed germination and floral development in Arabidopsis. Plant Physiology 569 135: 1008-1019.

570 Uemura M, Joseph RA, Steponkus PL. 1995. Cold acclimation of Arabidopsis thaliana: effect on 571 plasma membrane lipid composition and freeze-induced lesions. Plant Physiology 109: 15-30. 
572 Vergnolle C, Vaultier MN, Taconnat L, Renou JP, Kader JC, Zachowski A, Ruelland E. 2005.

573 The cold-induced early activation of phospholipase C and D pathways determines the response of

574 two distinct clusters of genes in Arabidopsis cell suspensions. Plant Physiology 139: 1217-1233.

575 Wijesinghe DS, Lamour NF, Gomez-Munoz A, Chalfant CE. 2007. Ceramide kinase and 576 ceramide-1-phosphate. Methods in Enzymology 434: 265-292.

577 Worrall D, Liang YK, Alvarez S, Holroyd GH, Spiegel S, Panagopulos M, Gray JE, 578 Hetherington AM. 2008. Involvement of sphingosine kinase in plant cell signalling. Plant Journal 579 56: 64-72.

580 Wu J-X, Li J, Liu Z, Yin J, Chang Z-Y, Rong C, Wu J-L, Bi F-C, Yao N. 2015. The 581 Arabidopsis ceramidase AtACER functions in disease resistance and salt tolerance. The Plant 582 Journal: For Cell and Molecular Biology. Accepted Article', doi: 10.1111/tpj.12769

583 Xu D, Huang X, Xu Z-Q, Schläppi M. 2011. The HyPRP gene EARLI1 has an auxiliary role for 584 germinability and early seedling development under low temperature and salt stress conditions in 585 Arabidopsis thaliana. Planta 234: 565-577.

586 Zhu J, Dong C-H, Zhu J-K. 2007. Interplay between cold-responsive gene regulation, metabolism 587 and RNA processing during plant cold acclimation. Current Opinion in Plant Biology 10: 290-295. 
591 Figure 1: A strongly hydrophobic phosphorylated sphingolipid accumulates upon cold exposure: (a) Cultured cells or (b) 14 day-old plantlets were exposed to $4{ }^{\circ} \mathrm{C}$ in presence of ${ }^{33} \mathrm{P}$ 593 orthophosphate, or were kept at $22^{\circ} \mathrm{C}$ for the indicated time. After extraction, radiolabelled 594 sphingolipids were developed on a TLC, detected by autoradiography, and quantified using a Storm 595 PhosphorImager. The TLCs presented are representative of $>4$ biological replicates. (c, d) 596 Quantification of the abundance of the lipid A expressed as a percentage of the total radioactivity 597 incorporated in the lane. Results represent means \pm SD of at least four independent experiments. 598 Asterisks indicate statistic differences determined by Student's test between lipid A abundance at $\mathrm{T}_{0}$ 599 and the other time points $(* *$ : $P<0.01)$. Rf were calculated from the TLC presented in 600 Supplementary figure $1 \mathrm{a}$.

601

Figure 2: acd5 mutants are defective in cold-induced lipid A accumulation: (a) Phenotype of 603 the 14 day-old plantlets used for ${ }^{33} \mathrm{PO}_{4}$ labelling in planta. Note that acd5 plantlets are 604 phenotypically identical to WT at this stage. (b) PR1 transcript abundance was analyzed by semi605 quantitative RT-PCR in RNA extracted from WT and acd5 14 day-old plantlets as well as as 606 positive control Salicilic acid treated WT plantlets. At this stage PR1 can not be detected in acd5 607 plantlets, further demonstrating that they are in the same condition as WT plantlets (c) Ratio of 608 radiolabelled lipid A abundance in cold-stressed $\left(3 \mathrm{~min}, 4^{\circ} \mathrm{C}\right)$ and unstressed $\left(3 \mathrm{~min}, 22^{\circ} \mathrm{C}\right) \mathrm{WT}$ and 609 acd5 plantlets. Results represent means \pm SD of four independent experiments, each composed of 610 five independent biological samples. Asterisks indicate statistic differences determined by Student's 611 test between $\operatorname{acd} 5$ and WT $(* *: P<0.01)$ 
614 shock. 14-days old plantlets were labeled as described in Material and Methods section. PHS-P and

615 Cer-P abundances were compared after ${ }^{33} \mathrm{PO}_{4}$ labelling in planta and expressed as fold increase 616 between cold-stressed $\left(3 \mathrm{~min}, 4^{\circ} \mathrm{C}\right)$ and unstressed $\left(3 \mathrm{~min}, 22^{\circ} \mathrm{C}\right)$ plantlets. Results represent means $617 \pm$ SD of three independent biological repeats. (a) Cold-induced increase of PHS-P abundance in WT 618 and acd5 mutant. (b) Cold-induced increase of Cer-P abundance in WT and LCB kinase mutants.

Figure 4: Cold affects ACD5 activity and gene expression in acd5 plantlets. (a) Crude protein extracts from cold-stressed $\left(3 \mathrm{~min}, 4^{\circ} \mathrm{C}\right)$ and unstressed $\left(3 \mathrm{~min}, 22^{\circ} \mathrm{C}\right) \mathrm{WT}$ and $\operatorname{acd} 5$ plantlets were 622 used for evaluation of in vitro Cer-K activity. Cer-K activity was assayed for 30 min, as described 623 in Material and Methods section, using C8-Cer and ${ }^{33} \mathrm{PO}_{4}$ as a substrate, in the absence or presence 624 of $50 \mu \mathrm{M}$ Cer-K K1 inhibitor. As controls, assays were carried in the absence of added lipid 625 substrate (C8-Cer) or protein extract. Figure shows a representative TLC obtained after 626 development of the radiolabelled sphingolipids. (b) The amount of ${ }^{33} \mathrm{P}-\mathrm{C} 8$-Cer formed by Cer-K 627 activity in vitro was determined after TLC development using a Storm PhosphorImager. Results 628 represent the ratio between ${ }^{33} \mathrm{P}-\mathrm{C} 8-\mathrm{Cer}$ formed in the different assays and that formed when extract 629 from unstressed control $\left(\mathrm{WT} / 22^{\circ} \mathrm{C}\right)$ is used. Data are given as mean $\pm \mathrm{SD}$ of six independent 630 biological repeats. Different letters indicate statistical differences determined by Student's test 631 (P<0.05). (c) ACD5 transcript abundance was analyzed by semi-quantitative RT-PCR in RNA 632 extracted from unstressed $\left(1 \mathrm{~h}, 22^{\circ} \mathrm{C}\right)$ and cold-stressed $\left(1 \mathrm{~h}, 4^{\circ} \mathrm{C}\right) \mathrm{WT}$ and $\operatorname{acd} 5$ plantlets. $S 19$ 633 transcripts were used as an internal standard.

635 Figure 5: acd5 plantlet phenotypes upon cold exposure. (a) acd5 and WT seedlings were grown 636 vertically at $22^{\circ} \mathrm{C}$ or $12^{\circ} \mathrm{C}$ as described in Material and Methods section. Primary root elongation 637 was recorded every two days over 8 to 28 days. Root elongation is expressed in cm/day and 
(b) Phenotypes of WT and acd5 Arabidopsis plantlets grown at $12^{\circ} \mathrm{C}$ (3 week-old) and $22^{\circ} \mathrm{C}$ (2 week-old). In these conditions spontaneous HR-like lesions were visible on $\operatorname{acd} 5$ plants after 3 weeks at $22^{\circ} \mathrm{C}$ and 5 weeks at $12^{\circ} \mathrm{C}$ (data not shown). (c)

641 Expression of $C B F s$, ZAT and NOI3 genes, analysed using semi-quantitative RT-PCR in 14-days 642 old WT and $a c d 5$ seedlings maintained at $22^{\circ} \mathrm{C}$ or transferred to $4{ }^{\circ} \mathrm{C}$ for $4 \mathrm{~h}$. Data are representative 643 of at least three repeats.

Figure 6: acd5 seed germination at low temperature. (a) acd5 and WT seeds were germinated at 4, 12 or $22^{\circ} \mathrm{C}$ in the dark. Germination rates were monitored after the indicated times (d: days) according to the temperature applied. Results are means \pm SD of 4 repeats ( $n>200$ seeds). Asterisks indicate statistic difference determined by Student's test between acd5 and WT in the same conditions (*: $P<0.05, * *: P<0.01$ ). (b) NCED3-9, ABI5 and RGL2 gene expression was analysed by semi-quantitative RT-PCR in WT and acd5 seeds germinated for 14 days at $4^{\circ} \mathrm{C}$. Results are representatives of 3 independent repeats. $18 S$ gene expression was used as a standard. (c) acd5 and WT seed germination was assayed at $4^{\circ} \mathrm{C}$ in obscurity, in presence or absence of $5 \mu \mathrm{M} \mathrm{GA}$, and germination rates were compared after 14 days. Results are means \pm SD of 4 repeats $(n>200$ seeds).

654

Figure 7: acd5 germination sensitivity to ABA. WT and acd5 seed germination was assayed 48h at $22^{\circ} \mathrm{C}$, in presence or absence of the indicated amount of ABA. Results are the means \pm SD of 5 repeats $(n>250$ seeds). Asterisks indicate statistic difference determined by Student's test between acd5 and WT in the same conditions (*: $P<0.05, * *: P<0.01)$.

659

660 Supplemental Figure 1: (a) evaluation of the lipid A Rf. 14 day-old plantlets were labelled with

$661{ }^{33} \mathrm{P}$-orthophosphate at 22 or $4{ }^{\circ} \mathrm{C}$ for $30 \mathrm{~min}$. Extracted lipids were developed on TLC and revealed 662 by autoradiography. Migration was stopped before migration front reached the top of the plate. Rf 
663

664

665

666

was calculated as the ratio of the distance of migration of a given molecule as compared to the migration front (1). (b) Co-migration of radiolabelled lipid A extracted from cold-stressed cultured cells $(\mathbf{C c})$ and plantlets $(\mathbf{P})$. Cultured cells or 14 day-old plantlets were exposed to $4^{\circ} \mathrm{C}$ for $5 \mathrm{~min}$ in presence of ${ }^{33} \mathrm{P}$-orthophosphate. After extraction, radiolabelled sphingolipids were developed on a TLC and detected by autoradiography. The signals corresponding to lipid A (A) and phytosphingosine-P (PHS-P) are indicated with arrows, together with the origin $(\mathrm{O})$ of migration.

\section{Supplemental Figure 2: Cold affects ACD5 activity and gene expression in acd5 plantlets.}

Crude protein extracts from cold-stressed $\left(3 \mathrm{~min}, 4^{\circ} \mathrm{C}\right)$ and unstressed $\left(3 \mathrm{~min}, 22^{\circ} \mathrm{C}\right) \mathrm{WT}$ and $\operatorname{acd} 5$ plantlets were used for in vitro Cer-K activity. Cer-K activity was assayed for $30 \mathrm{~min}$, as described in Material and Methods section, using C8-Cer as a substrate. As controls, assays were carried in the absence of added lipid substrate. Figure shows a representative TLC obtained after development of the radiolabelled sphingolipids.

As the assays were done by addition of ${ }^{33} \mathrm{P}$ ATP on crude extracts, unidentified non-specific bands due to various kinases activities are also present, as well as a faint band probably corresponding to the phosphorylation of the endogenous Ceramide (Cer-P).

Supplemental Figure 3: Relative expression levels of genes analyzed by RT-PCR. Relative intensities of the bands of interest presented in Figure 4c (a), Figure 5c (b) and Figure 6b (c) has been determined by image analysis using ImageJ sofware. It is expressed as the ratio between the intensity of the band of interest and that of the corresponding reference gene, after subtraction of background intensity.

Supplemental Table 1: Sequences of the primers used in this studies. 
(a)

$$
\text { cultured cells }
$$

$4^{\circ} \mathrm{C}$

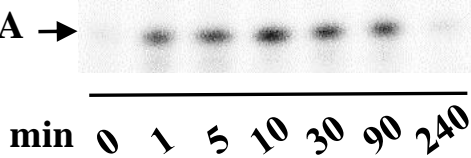

(c)

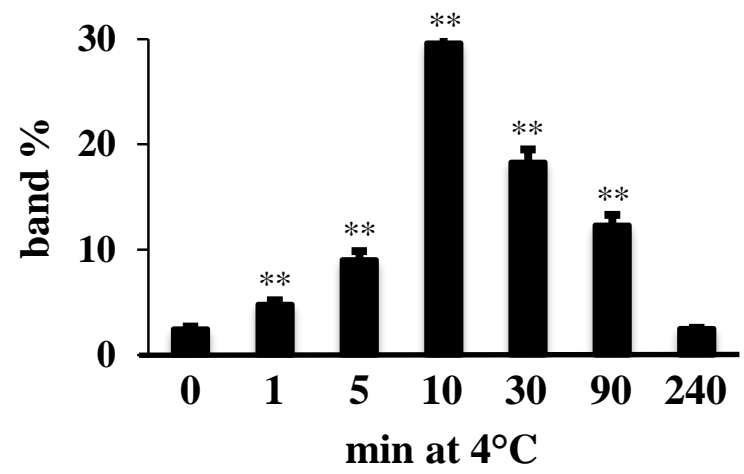

(b)

$$
\text { plantlets }
$$

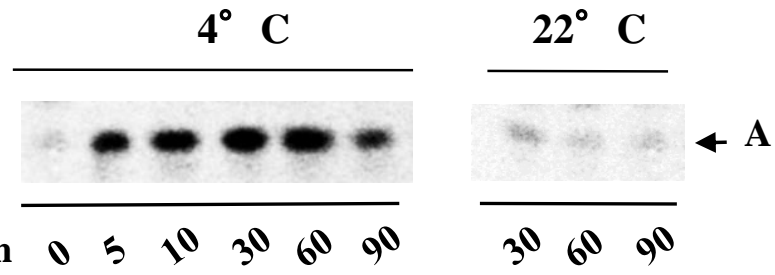

(d)

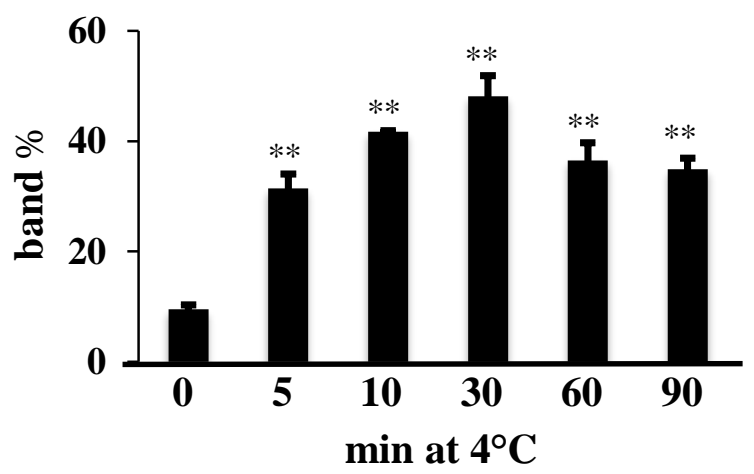


(a)
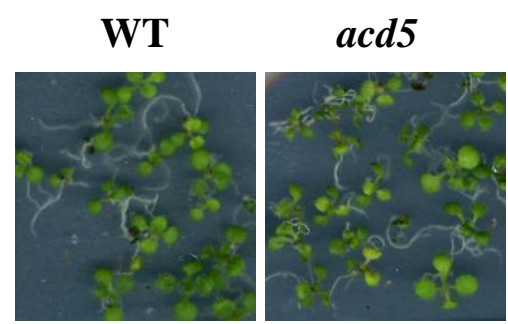

(b)

$$
\text { PR1 }
$$

S19

WT acd5 SA

(c)

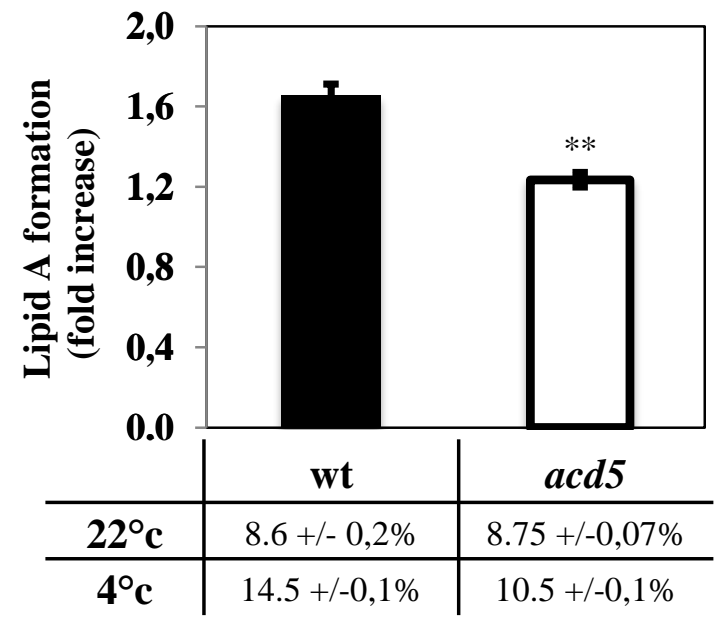

Figure 2 
(a)

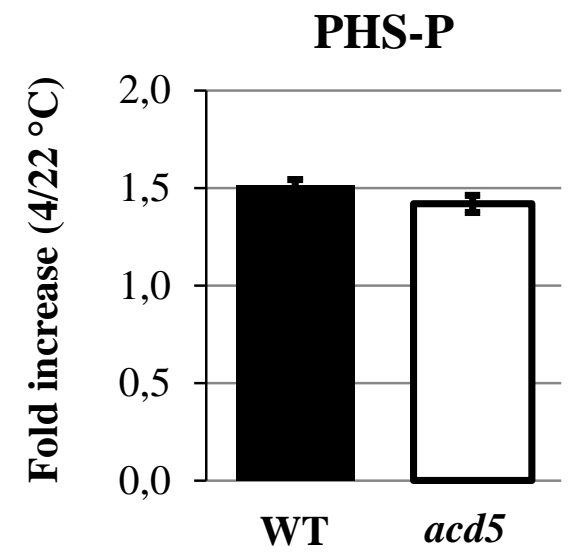

(b)

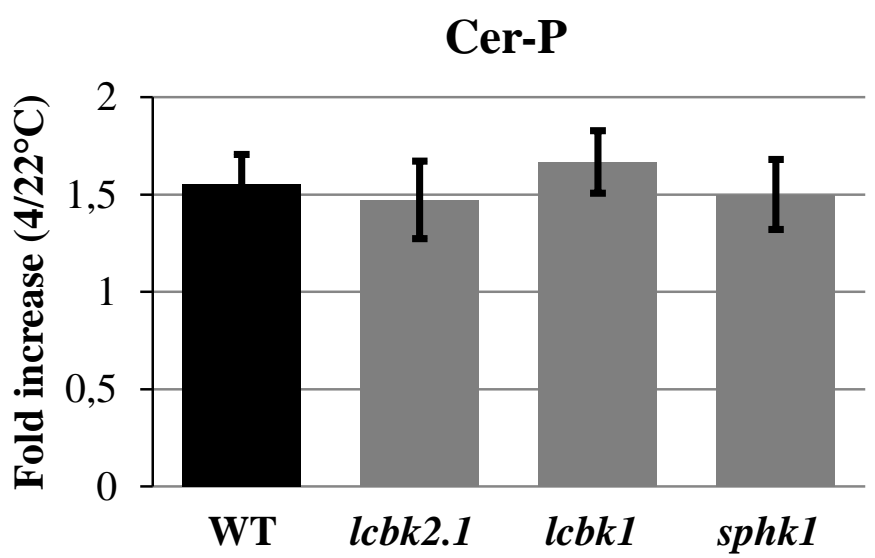

Figure 3 
(a)

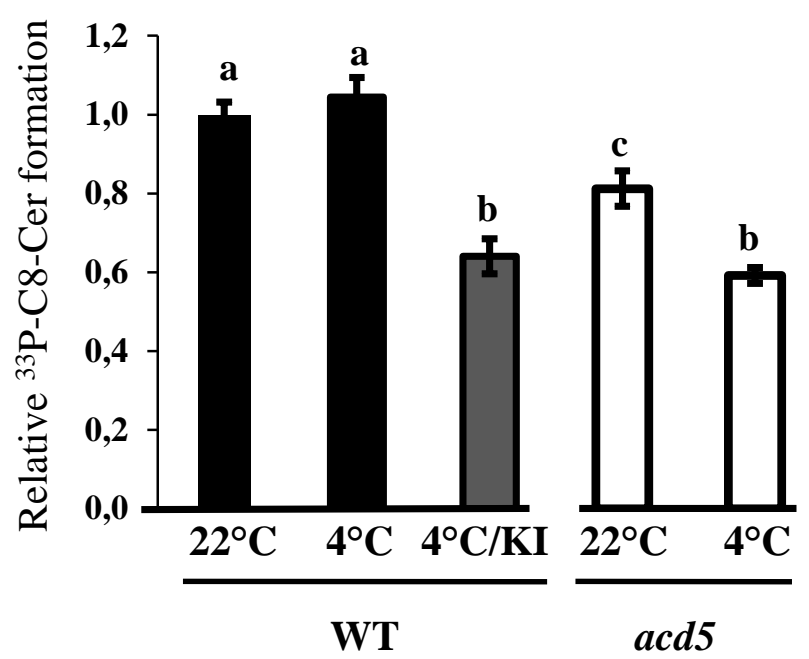

(b)

$$
\begin{aligned}
& \mathrm{C} 8-\mathrm{Cer}-\mathrm{P} \rightarrow--\infty-\infty-\infty{ }_{-\infty}{ }^{\text {acd5 }} \\
& \text { C8-Cer } \overline{++} \overline{++} \overline{++} \overline{++} \overline{-+} \overline{+}
\end{aligned}
$$

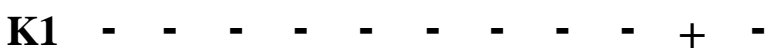

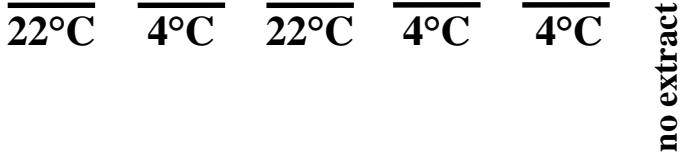

(c)

$$
\begin{aligned}
& \text { ACD5 } \\
& \text { S19 } \\
& \frac{\overline{22} \overline{4}}{W T} \frac{\frac{22}{4}}{a c d 5}{ }^{\circ} \mathrm{C}
\end{aligned}
$$


(a)
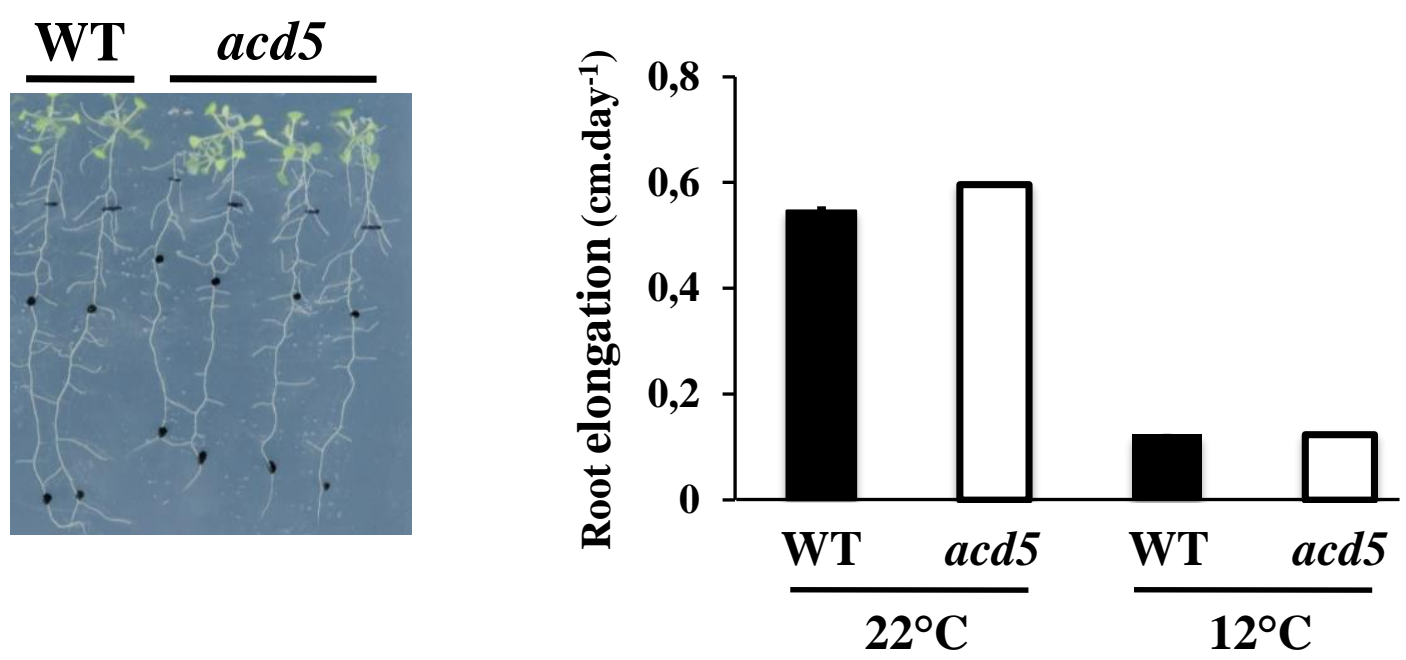

(b)

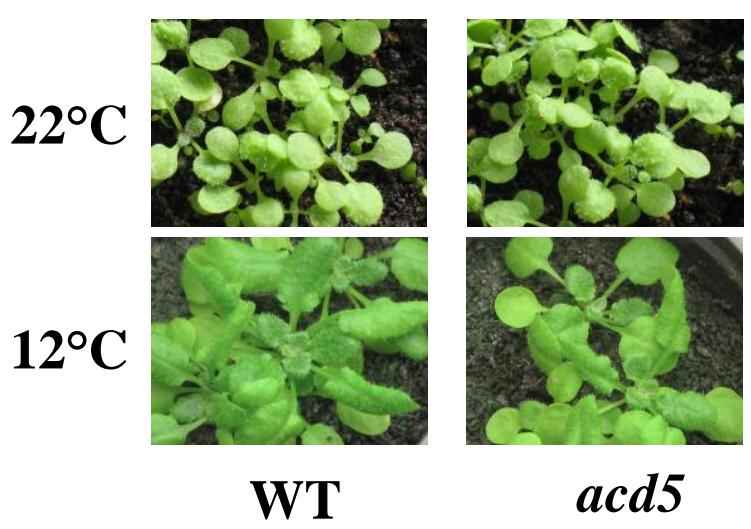

(c)

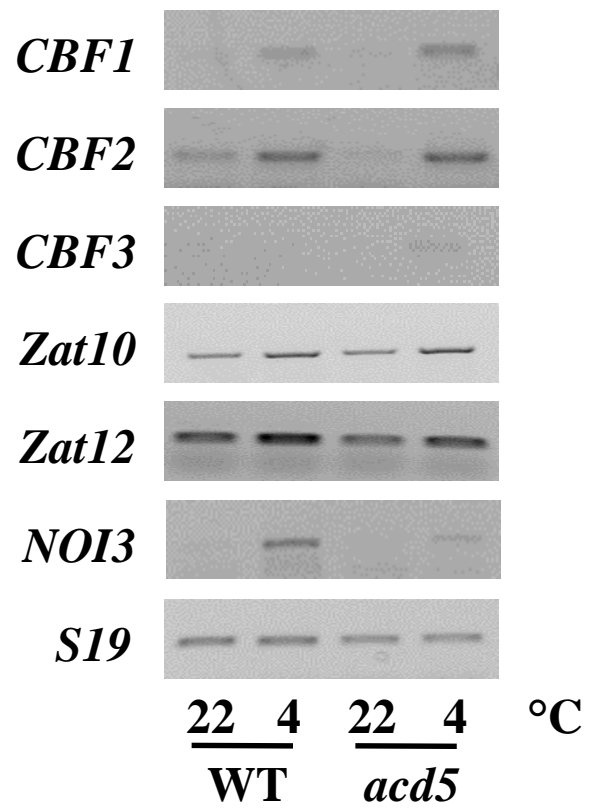

Figure 5 
(a)

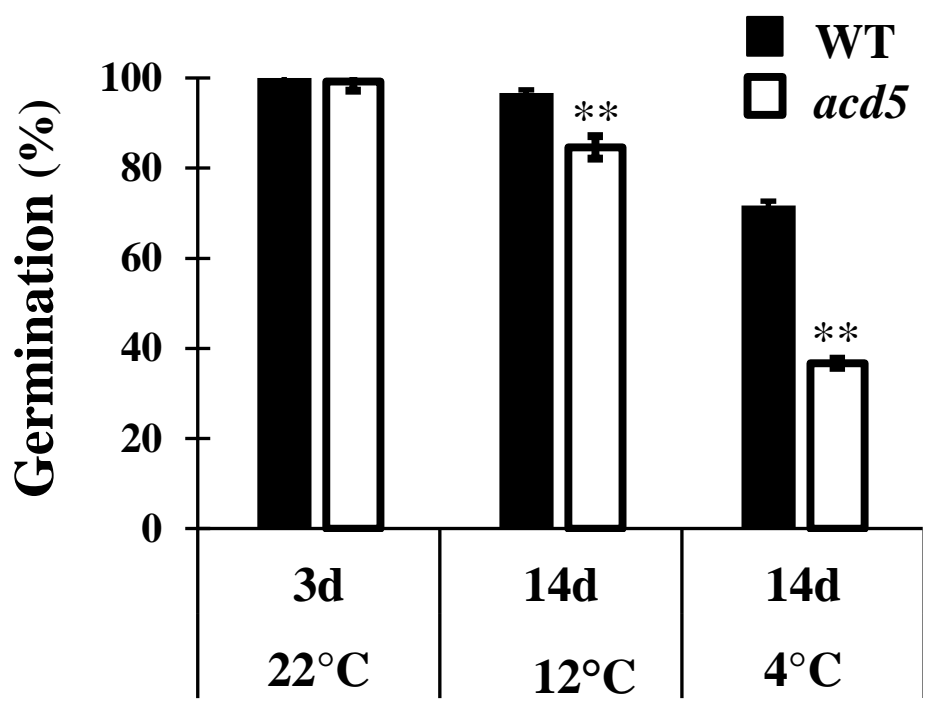

(b)

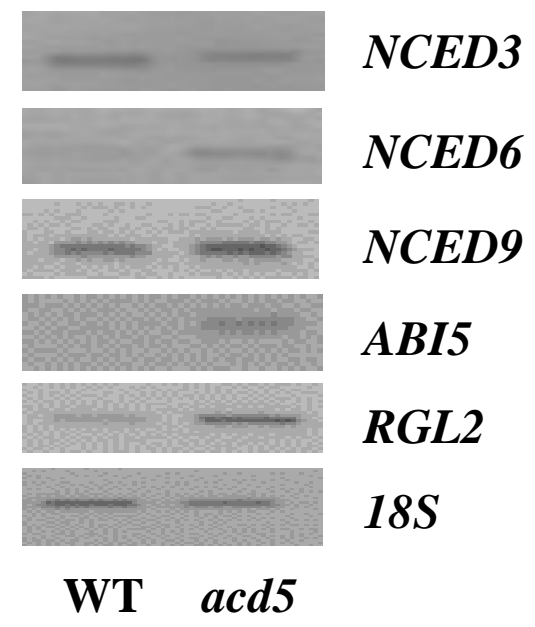

(c)

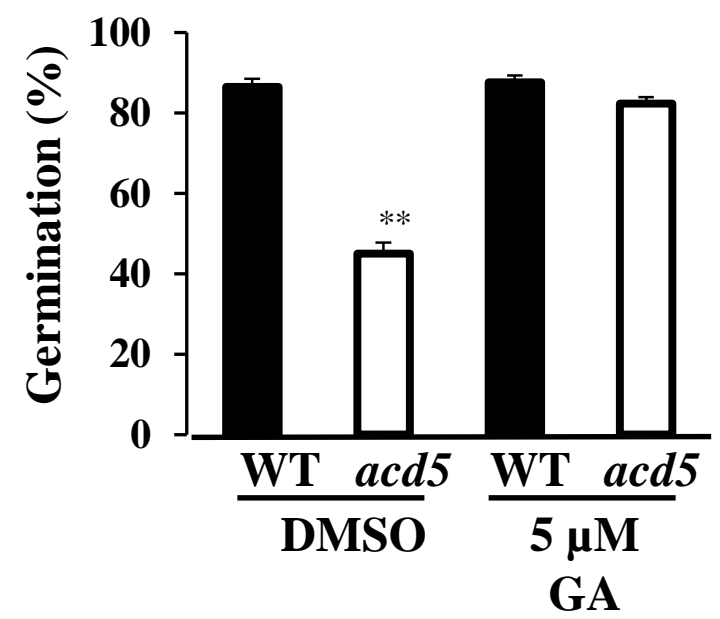

Figure 6 


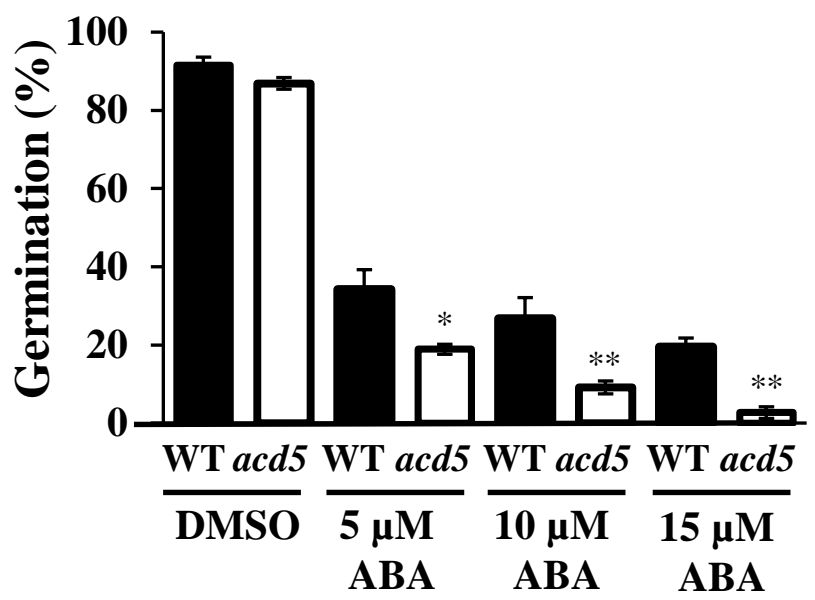

Figure 7 
a.

- 1

$\mathrm{A} \rightarrow=0 \cdot 0.67$

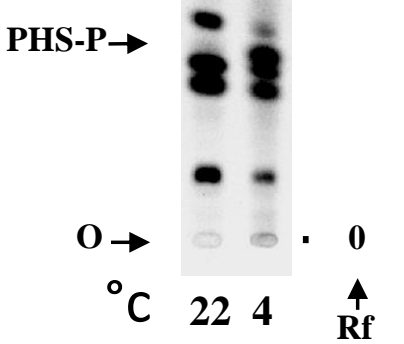

b. Ce P

A $\rightarrow$

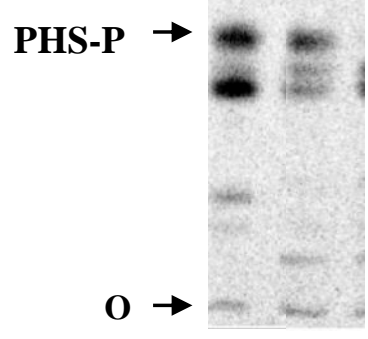




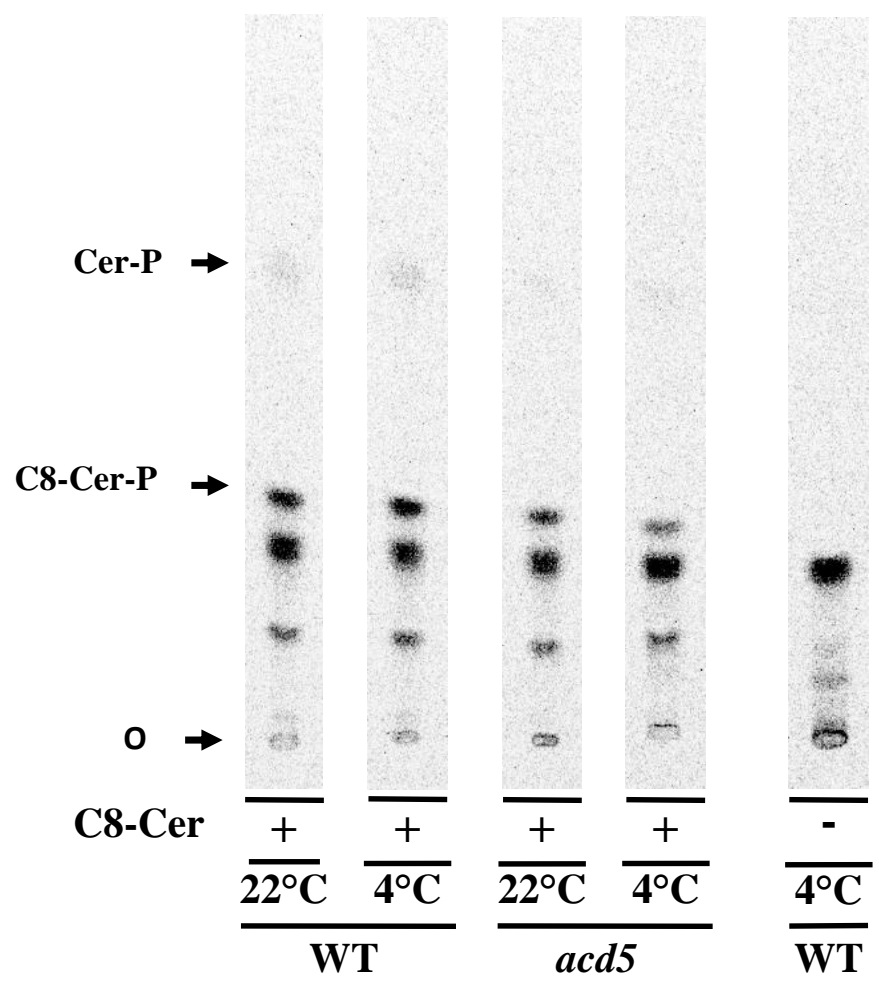

Supplemental figure 2 


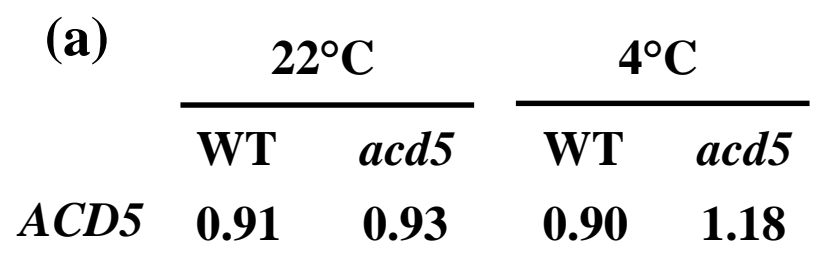

(b) $\frac{22^{\circ} \mathrm{C}}{\text { WT } \quad a c d 5} \frac{4^{\circ} \mathrm{C}}{\text { WT } \quad a c d 5}$

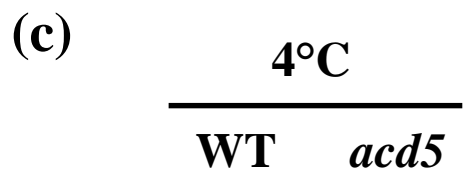

$\begin{array}{lllll}C B F 1 & 0.11 & 0.63 & 0.3 & 0.88\end{array}$

NCED3 $\quad 1.00 \quad 1.18$

$\begin{array}{lllll}C B F 2 & 0.69 & 1.21 & 0.35 & 1.43\end{array}$

$\begin{array}{lll}\text { NCED6 } & 0.37 & 1.00\end{array}$

$\begin{array}{lllll}C B F 3 & 0.13 & 0.24 & 0.01 & 0.31\end{array}$

$\begin{array}{lll}N C E D 9 & 1.88 & 2.36\end{array}$

$\begin{array}{lllll}Z A T 10 & 0.65 & 0.84 & 0.73 & 1.00\end{array}$

$\begin{array}{lll}A B I 5 & 0.03 & 1.21\end{array}$

$\begin{array}{lllll}Z A T 12 & 1,66 & 2.11 & 1.49 & 1.88\end{array}$

$\begin{array}{lll}R G L 2 & 0.56 & 2.00\end{array}$

$\begin{array}{lllll}\text { NOI3 } & 0.13 & 0.85 & 0.18 & 0.34\end{array}$ 


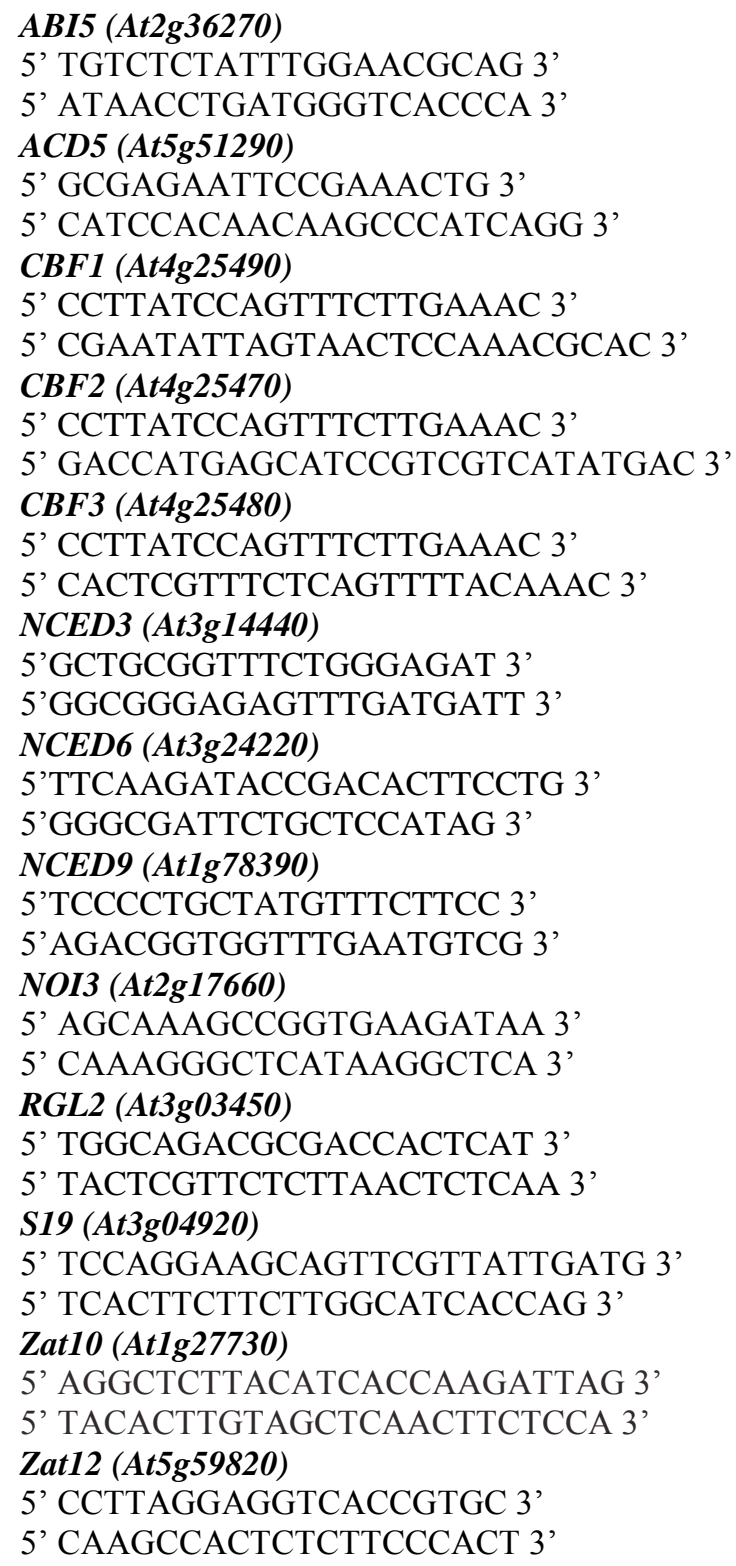

\section{Supplemental Table 1}

